УДК: 355.23(477):378.5

Дмитро Анатолійович Чопа (кандидат технічних наук, с.н.с.) ${ }^{1}$

Анатолій Йосипович Дерев'янчук (кандидат технічних наук, професор) ${ }^{2}$

Дмитро Андрійович Чехута

${ }^{1}$ Національний університет оборони Украӥни імені Івана Черняховського, Київ, Украйна
${ }^{2}$ Сумський державний університет, Суми, Украӥна

\title{
ДЕЯКІ АСПЕКТИ СТВОРЕННЯ ТА ЗАСТОСУВАННЯ МОБІЛЬНИХ ДОДАТКІВ ДЛЯ ВИВЧЕННЯ ВІЙСЬКОВО-ТЕХНІЧНИХ ДИСЦИПЛІН
}

Сучасні умови функиіонування Збройних Сил України, насамперед, підготовка військових фахівиів в режимі скороченого часу та обмежених можливостей навчальної матеріально-технічної бази обумовлює нові підходи до організації навчання та підготовки. Тому у статті розглядаються деякі аспекти щодо створення мобільних додатків військово-технічного призначення, які можна встановлювати на різноманітні мобільні пристрої та використовувати їх під час підготовки військових спеціалістів. Авторами розглядаються етапи створення мобільних додатків, принципи побудови, функиії та завдання, які мають вирішуватися мобільними додатками військово-технічного призначення.

Наведені результати аналізу педагогічного експерименту зі студентами, які навчаються на кафедрі військової підготовки Сумського державного університету, щуо дозволило зробити висновок про позитивний вплив використання мобільних додатків на підвищення якості та зростання рівня підготовки під час вивчення військово-технічних дисциплін.

Запропоновані напрями подальших досліджень щьодо створення мобільних додатків військовотехнічного призначення.

Ключові слова: мобільні додатки; мобільні пристрої; інтерфейс; користувач мобільного додатку; критерій Ст'юдента.

\section{Вступ}

Дану статтю слід розглядати як подальший аналіз шляхів підвищення ефективності підготовки військових фахівців 3 військовотехнічних питань за рахунок використання сучасних інформаційних технологій.

Постановка проблеми. Зараз існує нагальна потреба у вирішенні дуже складної проблеми: як здійснити якісну підготовку військових спеціалістів ракетних військ і артилерії (РВ і А) за короткий термін навчання (в умовах особливого періоду) та опанування зразками озброєння та військової техніки (ОВТ), що стоять на озброєнні Збройних Сил України, або швидко поновити отримані раніше та втрачені знання та практичні навички особовим складом, для ефективного виконання завдань у зоні проведення операції Об'єднаних сил (ООС).

Зазначені чинники вже висвітлювалися авторами в попередніх працях, де був здійснений аналіз основних стратегічних напрямів вирішення зазначеної проблеми. Досвід впровадження інформаційних технологій в навчання та підготовку військових фахівців надає широкі можливості для їх вдосконалення, а саме: підвищення мотивації до навчання; закріплення знань і практичних навичок; зменшення часу i коштів на підготовку; підвищення безпеки під час експлуатації ОВТ. Однак, при цьому, відслідковується недостатня орієнтація на підготовку фахівців у місцях виконання завдань, де відсутні мультимедійні та інші інтерактивні засоби навчання, а це позначається на якості підготовки фахівців, особливо у зоні бойових дій.

Слід зазначити, що розвиток мобільних пристроїв відкриває нові можливості у використанні їх в інтересах підготовки у будьякому місці, за будь-яких умов.

Мета дослідження полягає у подальшому пошуку та розвитку підходів щодо впровадження мобільних технологій у процес навчання спеціалістів у ВВН3, підготовки в військових частинах та навчальних центрах.

\section{Виклад основного матеріалу дослідження}

Для кожного викладача або командира прагнення досягти максимально можливого рівня знань тими, хто навчається, завжди було і $\epsilon$ професійною потребою та обумовлювало пошук шляхів до його здійснення.

3 розвитком інформаційних технологій, мобільних пристроїв та Internet технологій, відкриваються нові шляхи і можливості втілити задумки викладача, командира передати знання особовому складу, навчити їх мислити і приймати правильні рішення у нештатних ситуаціях.

Тому у статті, будуть розглянути деякі підходи щодо створення i застосування мобільних додатків, які можна використовувати на різних мобільних пристроях: смартфони; планшети; ноутбуки тощо.

Відмітимо, що мобільні додатки широко застосовуються у різноманітних галузях: бізнес, реклама і т. і., а у військовій галузі, зокрема для підготовки фахівців $\mathrm{PBiA}$, майже не використовуються.

Тому в статті будуть розглянуті завдання, функції та операції, які повинні виконувати мобільні додатки; як будуть оброблятися дані; як 
забезпечити зручність мобільного додатку для користувачів.

Аналіз досвіду створення мобільних додатків свідчить, що спроба відразу втілити в продукт повний набір функцій призводить до того, що мобільний додаток стає громіздким, складним i користуватися ним просто неможливо, так як він визначає не тільки стратегію і тактику у вивченні військово-технічних дисциплін (ВТД), інтеграцію інформаційних технологій у навчальний процес, але й дає ключові поняття цих технологій та раціональне їх використання.

Різні автори пропонують різні етапи створення мобільних додатків [2,3].

Огляд досліджень [1,4-6] показав, що кількість етапів буде залежати від відповіді на такі питання: для чого створюється цей додаток? Яку користь він принесе користувачам? Чи захочуть користувачі його використовувати? Яка аудиторія користувачів? Які переваги буде мати мобільний додаток перед іншими, якщо такі вже $\epsilon$ ?

Щоб знайти відповіді на ці питання потрібно провести аналіз запиту потреб користувачів. А для цього необхідно обгрунтувати їх зацікавленість (мотивацію) у використанні мобільного додатку.

Спочатку провести моніторинг цільової аудиторії та визначити іiї так звані “больові точки”, тобто з'ясувати їі потреби.

По-друге, визначити обсяг потреб наших користувачів.

По-третє, треба сформувати функціонал мобільного додатку i визначити його ключові можливості. Із наведеного вище, випливає потреба у визначенні ключових моментів, як повинен функціонувати мобільний додаток, а саме: що він повинен робити; які завдання, функції та операції він повинен виконувати (інтеграція 3 іншими додатками або контентом і т. і.), як він буде (якщо це потрібно) обробляти дані і чи буде збирати такі дані від користувачів.

Викладене вище є першим етапом, на якому розробляються варіанти використання для того, щоб зрозуміти, як користувачі будуть взаємодіяти 3 додатком. Зауважимо, що чим більше буде додано функцій, тим складнішим буде продукт i, відповідно, часу на його створення буде витрачено більше.

Найголовніше, що потрібно мати на увазі при розробленні мобільного додатку - переконатися, що він $\epsilon$ одночасно і корисним, та інтуїтивно зрозумілим. Добре продуманий дизайн інтерфейсу користувача вирішує обидві ці проблеми. Основні пріоритети щодо розроблення дизайну наведені нижче.

Видалення зайвого. Надлишковий інтерфейс перевантажує користувача занадто великим обсягом інформації: кожна нова кнопка, зображення або рядок тексту робить екран більш складним.

Очевидна навігачія. Допомога в навігації має бути головним пріоритетом будь-якої програми.

Встановлення правильних розмірів цілей натискання, кнопки тощо. По маленьких кнопках користувачу складніше влучити, ніж по великих. При створенні мобільного інтерфейсу кнопки та об'єкти натискання краще робити досить великими, щоб по них було простіше натиснути.

Текст повинен бути розбірливим. У порівнянні зі стаціонарними комп'ютерами, які комплектуються достатньо великими моніторами, мобільні гаджети мають відносно невеликі екрани, а це означає, що одна 3 проблем мобільного дизайну - вмістити великий обсяг інформації на маленькому UI (User Interface).

Елементи інтерфейсу має бути добре видно. Розробники повинні використовувати такий колір і контраст, щоб допомогти користувачам бачити та інтерпретувати зміст нашого додатку, тобто необхідно забезпечити зручність користування (useability).

Викладене вище, представляє собою другий eman створення мобільного додатку.

Розглянемо ще один важливий аспект технічних можливостей нашого додатку, які суттєво впливають на якість і інформативність додатку в цілому, а саме, анімацію.

Анімації використовуються коли користувач не має можливості спостерігати ті чи інші явища в реальному часі-просторі, наприклад, дію снаряда по броні, дію механізмів підривника при пострілі, у польоті, при зустрічі з перешкодою тощо.

Під час вивчення зразка ОВТ, наприклад, самохідних гармат, анімація дає можливість побачити всі вузли і механізми, які знаходяться всередині гармати, та їх дію. В даному випадку найбільш доцільно використовувати 3D, 3D-max моделювання 3 одночасним стислим описом того чи іншого явища, дії механізму, боєприпасу тощо.

Таким чином розглянуто третій eman створення мобільного додатку.

Після завершення процесу розроблення мобільного додатку потрібно перевірити, виявити неточності, помилки та інші негативні сторони програмного продукту.

Після того, як базовий функціонал протестований, необхідно переконатися, що мобільний додаток $\epsilon$ досить простим у використанні та забезпечує потрібний результат для користувача.

Тестування сумісності. Мобільні пристрої розрізняються залежно від платформи, моделі та версії їх операційної системи. Важливо обрати таку підмножину пристроїв та програмного забезпечення, яка буде відповідати нашому додатку.

Необхідно врахувати вплив зовнішніх чинників, а саме, наявність інших мобільних додатків на пристрої, які можуть негативним чином впливати на роботу знов розробленого додатку.

Викладене вище представляє собою четвертий та п'ятий етапи. Таке поєднання відбувається тому, що низка процедур із забезпечення потреб користувача відбувається на етапі тестування. Процедура, яка не відбувається на етапі тестування - це розміщення додатку в мережі Internet.

Загальна схема розроблення мобільного додатку представлена на рис. 1 . 


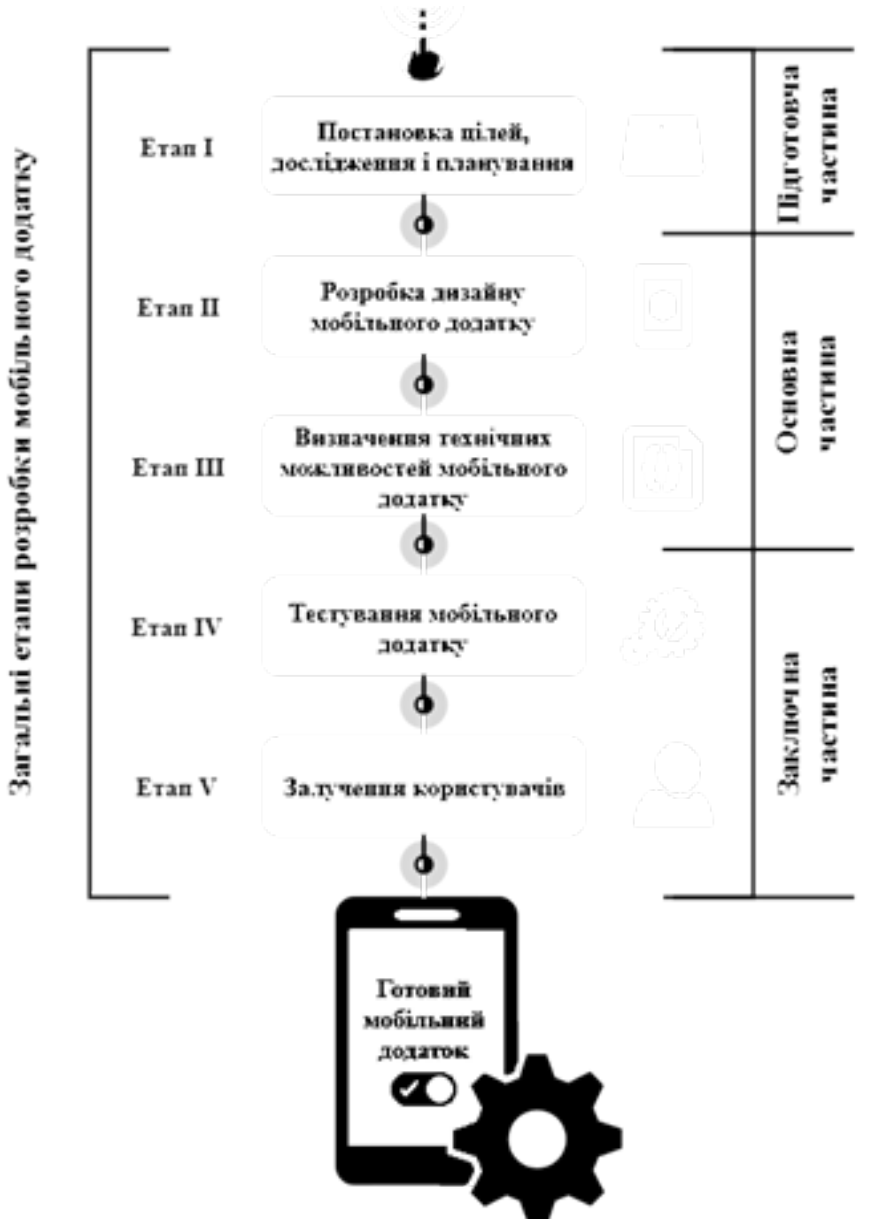

Рис. 1. Етапи створення мобільного додатку

Вибір операиійної системи (OC). Пропонується використання OC Android, тому що саме ця ОC найбільше розповсюджена серед користувачі мобільних пристроїв, забезпечує більш дешеве та доступне розроблення. Крім того, мобільний додаток під ОС Android дає доступ до широкої аудиторії фахівців. Як приклад, розглянемо розроблений мобільний додаток “152-мм самохідна гаубиця 2С3M. Це дуже просто (Вивчаємо за 10 днів)".

Скріншоти інтерфейсу та приклади користування мобільним додатком наведені на рис. 2, 3 .

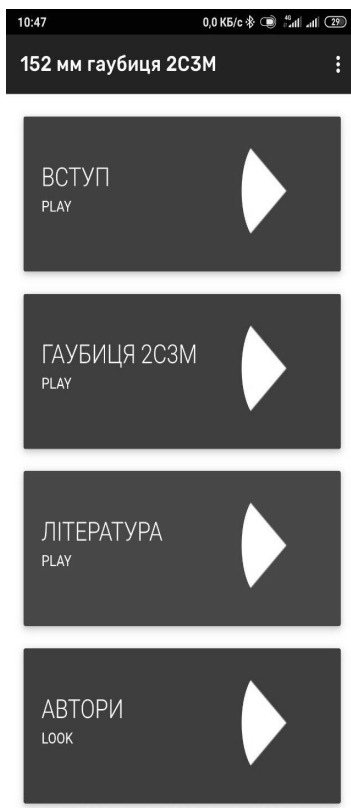

a)

\begin{tabular}{l}
\hline $10: 47$ \\
152 мм гаубИця 2СЗМ \\
\hline 152 ММ ГАУБИЦЯ 2С... \\
\hline ДЕНЬ ПЕРШИЙ \\
\hline ДЕНЬ ДРУГИЙ \\
\hline ДЕНЬ ТРЕТІЙ \\
\hline ДЕНЬ ЧЕТВЕРТИЙ \\
\hline ДЕНЬ П'ЯТИЙ \\
\hline ДЕНЬ ШОСТИЙ \\
\hline ДЕНЬ СЬОМИЙ \\
\hline ДЕНЬ ВОСЬМИЙ \\
\hline
\end{tabular}

б)

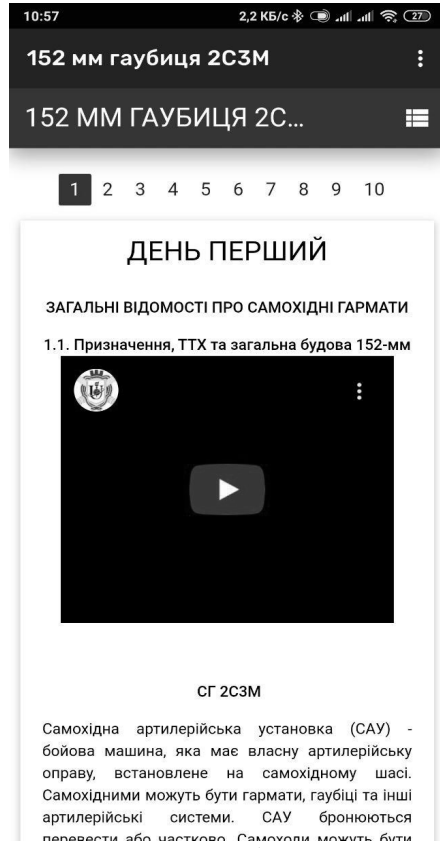

B)

Рис. 2 Скріншоти інтерфейсу мобільного додатку (а - навігація додатку; б - зміст додатку; в - перехід із змісту на пункт навігації (день 1-й)) 

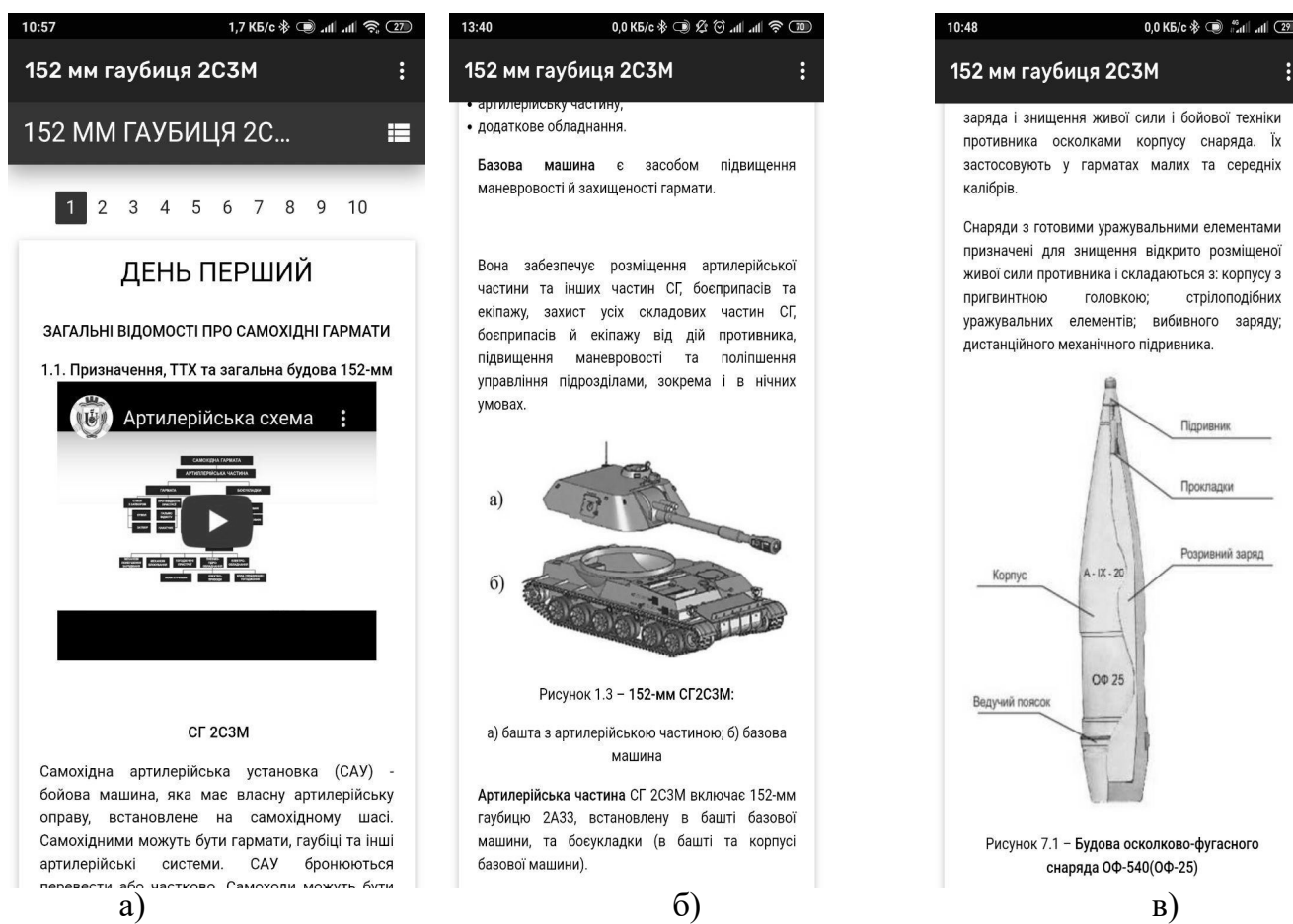

Рис. 3 Скріншоти з мобільного додатку (а - використання відео у додатку; 6 - використання анімації при вивченні будови 2С3М (день 1-й); в - використання анімації при вивченні будови осколковофугасного снаряда (день 7-й))

Після створення мобільного додатку можна розглянути його переваги, які наведені на рис. 4.

3 метою перевірки доцільності застосування мобільного додатку був організований демонстраційний експеримент.

На початку використання мобільного додатку у процесі навчання результати не відповідали очікуванням, 3 достатньою кількістю помилок $\mathrm{i}$ значною витратою часу.

На проміжному етапі процес навчання із застосуванням мобільного додатку показав зростаючу динаміку. Паралельно була запропонована методика оцінки застосування мобільного додатку в процесі навчання студентів.

Таким чином, використовуючи методику оцінки застосування мобільного додатку було досліджено вплив мобільного додатку на процес навчання студентів. Взвод був поділений на дві групи по 13 чоловік у кожній. Перша група використовувала традиційний метод, як на планових заняттях, так і під час самостійної підготовки.

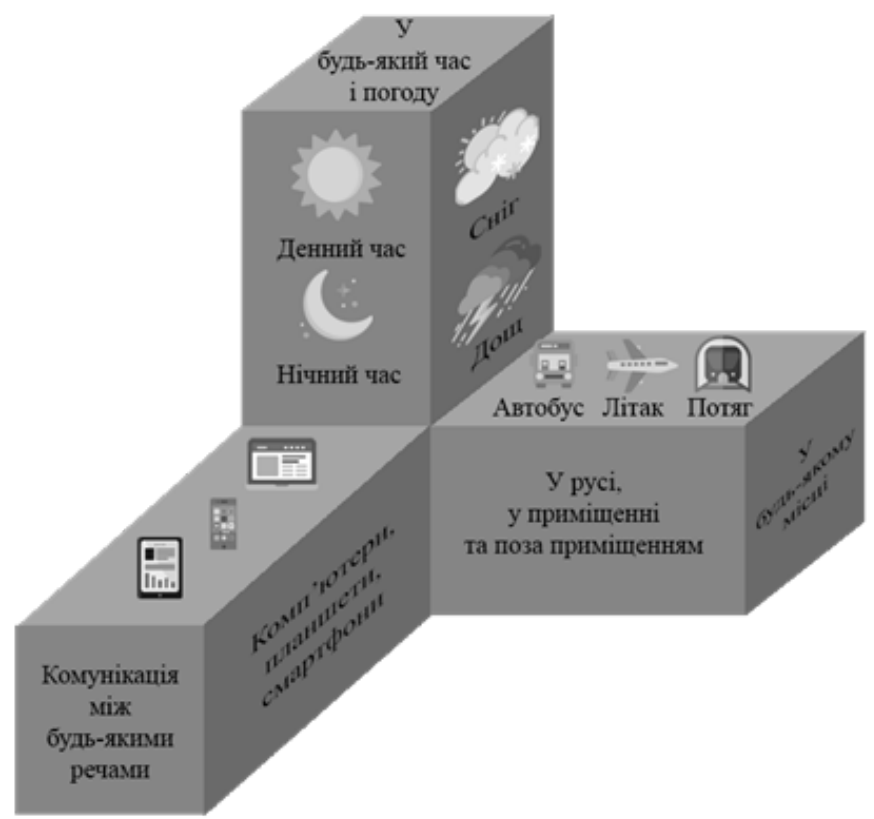

Рис. 4 Переваги використання мобільного додатку перед традиційними методами навчання

У другій групі проводилось заняття 3 впливу інноваційного метода навчання використанням мобільного додатку.

Результати досліджень у згаданих вище групах наведені у таблиці 1. Було перевірено гіпотезу

(застосування мобільного додатку) на підготовку студентів 3 рівнем значимості 0,05 . У даному випадку представлені парні вибірки. 
Таблиця 1

Порівняльні результати визначення рівнів розвитку студентів на традиційних заняттях та заняттях із використанням мобільного додатку

\begin{tabular}{|c|c|c|c|c|}
\hline Студенти & $\begin{array}{c}\text { До проведення } \\
\text { занять }\end{array}$ & Після проведення & Різниця величин & $\begin{array}{c}\text { Квадрат } \\
\text { різниці }\end{array}$ \\
\hline 1 & 45 & 53 & 8 & 64 \\
\hline 2 & 37 & 42 & 5 & 25 \\
\hline 3 & 64 & 80 & 16 & 256 \\
\hline 4 & 65 & 73 & 8 & 11 \\
\hline 5 & 56 & 67 & 14 & 196 \\
\hline 6 & 65 & 81 & 16 & 256 \\
\hline 7 & 52 & 68 & 8 & 49 \\
\hline 8 & 80 & 92 & 7 & 10 \\
\hline 9 & 78 & 85 & 10 & 144 \\
\hline 10 & 77 & 87 & 12 & 81 \\
\hline 12 & 72 & 84 & 9 & 81 \\
\hline
\end{tabular}

Подальші розрахунки (результати) отримані після проведення статистичного аналізу даних за допомогою розрахунку критерію Стююдента i наведені у таблиці 2.

Аналіз та обробка отриманих експериментальних даних шляхом проведення контрольних заходів, відбувалась із застосування статистичного критерію Ст'юдента. Відповідно до результатів аналізу, можна зробити висновок, що гіпотеза, яка перевірялася, має право на існування, про що свідчить порівняння отриманого значення критерію Ст'юдента із табличним.

Отримане значення критерію Ст'юдента $t_{c}$

менше табличного, що в, свою чергу, підтверджує висунуту гіпотезу. Маючи результати перевірки гіпотези, можна зробити висновок, що особовий склад групи 2, підготовка якого відбувалась 3 використанням мобільного додатку, ефективніший, успішніший, має більш якісний показник отриманих знань за групу 1, підготовка якої здійснювалась традиційним способом.

Обчислений показник ефективності групи 2 дає можливість побачити наскільки ефективніше відбувається підготовка військових спеціалістів 3 використанням мобільного додатку.

Таблиця 2

Результати аналізу порівняння підготовки двох груп традиційним та інноваційним способами

Група № 1 - Традиційний спосіб підготовки

Група № 2 - підготовка взводу з використанням мобільного додатку

\begin{tabular}{|c|c|c|}
\hline \multicolumn{2}{|c|}{ Група № $1-$ Традиційний спосіб підготовки } & \multicolumn{2}{c|}{$\begin{array}{c}\text { Група № 2 - підготовка взводу з використанням } \\
\text { мобільного додатку }\end{array}$} \\
\hline$M=11,4$ & Обчислення математичного очікування & $M=13,6667$ \\
\hline$S=1,24845$ & Обчислення середньоквадратичного відхилення & $S=0,49013$ \\
\hline Обчислюємо значення критерію Ст'юдента та порівнюємо його з табличним значенням, для прийняття або \\
відхилення гіпотези, що перевіряється.
\end{tabular}

Показник ефективності E визначається за формулою (1):

$$
\mathrm{E}=\left(\frac{\mathrm{M}_{2} \cdot 100}{\mathrm{M}_{1}}\right)-100
$$

де: $\mathrm{M}_{1}, \mathrm{M}_{2}$ - обчислене математичне очікування для груп $1,2$.

Обчислення формули (1) показали, що ефективність групи 2 у порівнянні із групою 1 більша на 19,88 \%, що в свою чергу, підтверджує доцільність впровадження та ефективність використання мобільного додатку у процесі підготовки військових спеціалістів. 3 метою удосконалення створення мобільних додатків та методики їх застосування серед студентів проведено опитування щодо його оцінки. Результати опитування відображені на рис.5.
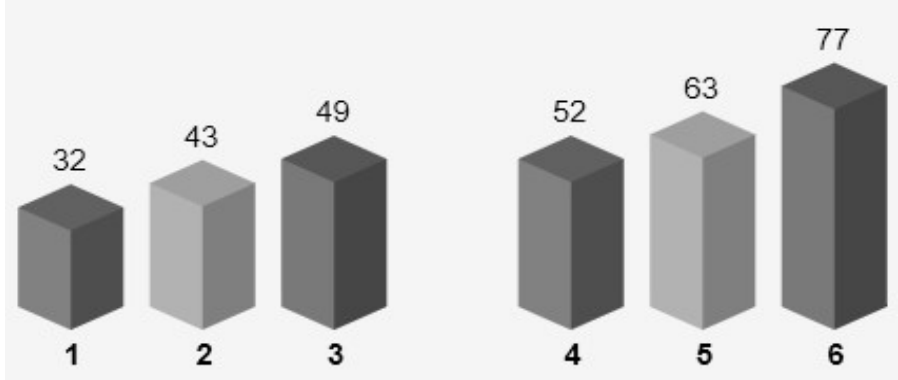

Рис. 5 Рівень оцінювання мобільного додатку студентами $(1,2,3,4,5,6$ - умовні позначення навчальної групи)

Приблизно $11 \%$ студентів не оцінили застосування мобільного додатку через складність інтегрування застосування мобільного додатку до традиційних методів навчання (на рисунку не показано) 


\section{Висновки і перспективи подальших досліджень}

Таким чином, в статті розглянуті основні етапи створення та використання мобільного додатку. Це дозволяє зробити висновок про доцільність їх впровадження як в теорію, так і в практику організації

\section{Лimepamypa мобильных приложений 1. Разработка bout/news-article/razrabotka \\ https://ru.flamix.software/about/news-article/raz mobilnykh-prilozheniy/. 2. Этапы разработки мобильных приложений https://appsstudio.ru/etapy-razrabotki-mobilnogo- prilozheniya. 3. Этапы разработки мобильного приложения http://www.orthedu.ru/ news/13655-etapy-razrabotki-mobilnogo- prilozheniya.html. 4. Создание мобильного приложения за 1 \\ месяц. Реальность или миф? https://inostudio.com/ru/article/mobile app sroki.html. 5. Полат E.C. Новые педагогические и информационные технологии в системе образования. Москва. Академия, 2002. 272 с. 6. Принципы дизайна мобильных приложений от google https://pgenerator.ru/ blog/ 2016/04/05/ principy - dizajna- mobilnyh-prilozhenij-ot-google/. \\ НЕКОТОРЫЕ АСПЕКТЫ СОЗДАНИЯ И ИСПОЛЬЗОВАНИЯ МОБИЛЬНЫХ ПРИЛОЖЕНИЙ ДЛЯ ИЗУЧЕНИЯ ВОЕННО-ТЕХНИЧЕСКИХ ДИСЦИПЛИН}

освітнього процесу та підготовки військових фахівців.

Подальші дослідження щодо розроблення та використання мобільних додатків доцільно присвятити розробці web-peсурсу, що дозволить вирішити проблеми сумісності 3 операційними системами та іншими мобільними та стаціонарними пристроями.

\author{
Дмитрий Анатольевич Чопа (кандидат технических наук, с.н.с.) ${ }^{1}$ \\ Анатолий Йосипович Деревьянчук (кандидат технических наук, профессор) ${ }^{2}$ \\ Дмитрий Андреевич Чехута
}

\title{
${ }^{1}$ Национальный университет обороны Украины имени Ивана Черняховского, Киев, Украина ${ }^{2}$ Сумськой государственный университет, Суммы, Украина
}

Современные условия функиионирования Вооруженных Сил Украины, прежде всего, подготовка военных специалистов в режиме сокращенного времени и ограниченных возможностей учебной материально-технической базы обусловливает новые подходы к организаџии обучения и подготовки. Поэтому в статье рассматриваются некоторые аспекты по созданию мобильных приложений военно-технического назначения, которые можно устанавливать на различные мобильные устройства и использовать их при подготовке военньх спечиалистов. Авторами рассматриваются этапы создания мобильных приложений, принџипы построения, функции и задачи, которье должнь решаться мобильными приложениями военно-технического назначения.

Приведенные результаты анализа педагогического эксперимента со студентами, которые учатся на кафедре военной подготовки Сумского государственного университета, позволило сделать вывод о положсительном влиянии использования мобильньх приложений на повыление качества и рост уровня подготовки при изучении военно-технических дисииплин.

Предложены направления дальнейших исследований по созданию мобильных приложений военнотехнического назначения.

Ключевые слова: мобильные приложения; мобильные устройства; интерфейс; пользователь мобильного приложения; критерий Стьюдента.

\section{SOME ASPECTS OF CREATING AND USING MOBILE APPLICATIONS FOR THE LEARNING OF MILITARY TECHNICAL DISCIPLINES}

\author{
Dmitro Chopa (Candidate of technical sciences, Senior Research Fellow) ${ }^{1}$ \\ Anatolii Derevianchuk (Candidate of technical sciences, professor) ${ }^{2}$ \\ Dmitro Chehuta
}

\section{${ }^{1}$ National Defence University of Ukraine named after Ivan Cherniakhovsky, Kyiv, Ukraine} ${ }^{2}$ Sumy State University, Sumy, Ukraine

Modern conditions for the functioning of the Armed Forces of Ukraine, first of all, the training of military specialists in the conditions of reduced time and limited capabilities of the educational and training base determines new approaches to the organization of education and training. Therefore, the article discusses some aspects of development military-technical mobile applications that can be installed on various mobile devices and used in training military specialists. The authors consider the stages of creating mobile applications, the principles of construction, functions and tasks that should be solved by mobile military-technical applications.

The results of the analysis of the pedagogical experiment with students who are studying at the Department of Military Training of Sumy State University allowed us to conclude that the use of mobile applications has a positive effect on improving the quality and increase of the level of training in the learning of military-technical disciplines.

The directions of further research on the development of mobile military-technical applications are proposed.

Keywords: mobile applications; mobile devices; interface; mobile application user; Student criterion.

\section{References}

1. Razrabotka mobilnyih prilozheniy [Mobile Application Development]. https://ru.flamix.software/about/news-article/ razrabotka-mobilnykh-prilozheniy/. 2. Etapyi razrabotki mobilnyih prilozheniy [Mobile applications development stages]. https://appsstudio.ru/etapy-razrabotki-mobilnogo-prilozheniya. 3. Etapyi razrabotki mobilnogo prilozheniya [Mobile application development stages]. http://www. orthedu.ru/ news/13655-etapyrazrabotki-mobilnogo-prilozheniya.html. 4. Sozdanie mobilnogo prilozheniya za 1 mesyats. Realnost ili mif? [Creation of a mobile applicationin 1 month.Reality or myth]. https://inostudio.com/ru/ article/mobile app sroki.html. 5. Polat E. (2002). Novyie pedagogicheskie $\bar{i}$ informatsionnyie tehnologii $\mathrm{v}$ sisteme obrazovaniya [New pedagogical and information technologies in the education system]. Moskva. Akademiya. 6. Printsipyi dizayna mobilnyih prilozheniy ot google [Google mobile app design principles]. https://lpgenerator.ru/ blog/2016/04/05/ principy dizajna-mobilnyh-prilozhenij-ot-google/. 